\title{
MANAGERS OF AGED CARE RESIDENTIAL SERVICES: 2006- 2016
}

\author{
Jo. M. Martins' \& Godfrey Isouard² \\ 1. Centre for Health Policy and Management \\ 2. University of New England, Australia \\ Correspondence: gisouard@une.edu.au
}

\section{ABSTRACT}

\section{PURPOSE}

Aged care Australia is going through a transformation reform to respond to the growing number of aged people in need of support in daily living. In this context, this article provides analyses of the number and characteristics of managers of aged care residential services in relation to number of aged people, residents of aged care facilities and people employed in them.

\section{METHODOLOGY/DESIGN}

Design of the analyses follows specifications provided by the authors for tabulations prepared by the Australian Bureau of Statistics (ABS) from the censuses of population conducted by ABS in 2006 and 2016.

\section{ANALYSIS}

Analysis of changes of the number of managers of aged care residential facilities against the number of aged people, residents of aged care facilities, and people employed in them. Further, the analyses examine changes in the age and sex of managers, their category, field and level of education, weekly income, hours worked, marital status, country of birth and indigenous status.

\section{FINDINGS}

There was a large increase in the number of employees and managers per resident, and a stable ratio of managers per employees. While the proportion of female managers declined, the average age of managers increased slightly. Both the fields and level of education remained similar in the decade. The average income of managers was similar as that in all industries in 2016, with a larger increase during the decade than in all industries. Average hours worked remained about the same. The same applied to marital status. The proportion of Australia-born managers declined while that of managers born in Asia rose substantially. The proportion of indigenous managers about doubled during the decade.

\section{IMPLICATIONS}

Relevance to those concerned with the evolving transformation of aged care in Australia and those interested with management training of the growing number of managers of aged care residential services. nalysis

\section{KEYWORDS}

health service managers, aged care residential services, health labour force, training and career path development

\section{GROWING DEMAND FOR AGED CARE RESIDENTIAL SERVICES}

Australia's population grew substantially in the decade 2006-2016, at the average rate of $1.64 \%$ per year. However, the number of people 70 years of age and older increased at the considerably greater average annual rate of $2.76 \%$. Consequently, as older people suffer from a greater degree of disability than the average, the demand for their support is rising. The relevance of the services provided is dependent on the type and degree of disability experienced. What has been described as transformation reform has taken place to enhance the appropriateness of the services rendered. [3] The range of services provided 
may take the form of varying degrees of support in the community, at home or in aged care residential facilities in hostels or nursing homes. The delivery of community and home support services has risen substantially reducing the need for residential care, but the number of people in aged care residential services still grew from about 154,900 in 2006 to 181,000 in 2016: an average annual rate of $1.56 \%$. [2] [3] In this context, the number of people employed in aged care residential services rose from 128,300 in 2006 to 211,600 in 2016, an average annual rate of $5.0 \%$, and the number of managers from 6,200 in 2006 to 10,200 in 2016, at the same rate of increase. [8] [1] The analyses in this paper are concerned with the characteristics of managers of age care residential services and changes that have taken place in the 10-year period 2006-2016, which have relevance to the organisation and management of these services and those concerned with management training.

\section{DATA SPECIFICATIONS}

The data are from the Census of Population and Housing conducted by the Australian Bureau of Statistics (ABS) in 2006 and 2016. The authors provided the specifications for the tabulations prepared by ABS. The occupation and industry classifications used by ABS were the same for the 2006 and 2016 censuses. The detail of these classifications was provided in the first article prepared by the authors on this matter. [4] The same applied to the demographic and other characteristics used by ABS. The data relate to four categories of managers: managers not further defined $(M(n f d))$, chief executive officers/general managers (CEO/GM), specialist and service managers. The industry of employment is Aged Care Residential Services. The specification of other variables followed ABS' coding of age, sex, marital status, field of study, level of education, country of birth, Indigenous status, individual income and hours worked. The hours worked and income related to the week before the census. For comparison purposes, the authors also requested information on health services and all industries (excluding farmers and farm managers). Other data in the analyses are from sources given by the authors. The authors followed ABS definitions of sex and gender. Sex is defined as the biological characteristics of males and females. Gender refers to psychological and social characteristics that are culturally determined from belief systems as to what masculine and feminine behaviour is or ought to be. ABS changed figures in some cells of the tabulations to avoid the unlikely identification of individuals. This resulted in small differences in the figures provided.
Nevertheless, this did not affect in a material way the results of the analyses carried out by the authors. It should be stated that although the basic data was provided by ABS in tabulations according to the authors' specifications, most of the figures and the information in the tables are the result of the authors' analyses.

\section{CHANGE IN GROWTH}

Efforts to provide services in the community and at home to the growing number of older people have resulted in a lower growth in the number of older people in aged care residential services in the period 2006-2016, while the number of people employed increased at a larger rate than the resident population in these facilities (Table 1).

Accordingly, the number of people resident in aged care residential services fell from 82.1 per thousand people aged 70 years and over in 2006 to 72.8 in 2016 . The increase in the number of employees led to a reduction in the number of residents per employee from 1.207 in 2006 to 0.856 in 2016. The ratio of the number of employees per manager remained about the same (20.7 employees per manager) during that period (Table 2).

\section{NUMBER OF MANAGERS BY CATEGORY}

The transformation reform of aged care in general and residential services in particular led to an increase of $64.9 \%$ in the number of managers of aged care residential services that kept up with the growth in the number of people employed during the decade 2006-2016. This fast rate of growth of managers was well above the proportional increase in health services (51.5\%) and about three times the average for all industries (21.8\%) (Table 3).

The number of managers concerned with ancillary services such as catering, cleaning and maintenance (+68.2\%), and to a lesser extent top executives ( $+66.1 \%$ ), increased at a somewhat higher rate than the average, with specialist managers growing at the lowest rate of all managers (+63.8\%) during the period 2006-2016 (Table 4).

However, the ratio of top executives (CEO/GM/Mnfd) to service and specialist managers in 2016 (8.55) remained almost the same as that in 2006 (8.50) with minor changes 
in the service manager $(+0.04)$ and the specialist manager $(-0.09)$ ratios (Fig. 1).

\section{SEX AND AGE OF MANAGERS}

The labour force of aged care residential services was mostly female both in 2006 (87.4\%) and 2016 (83.7\%). Females also constituted the majority of managers in 2006 (66.2\%) and 2016 (64.2\%). However, there was a gap between the proportion of females in the labour force and the proportion of female managers in both years: $21.2 \%$ in 2006 and $19.5 \%$ in 2016 (Table 5).

The proportion of female managers was highest in the case of specialist managers, $74.0 \%$ and $70.9 \%$ in 2006 and 2016 respectively, and lowest in the aggregate categories of chief executive/general manager/manager not further defined: $45.1 \%$ and $49.5 \%$ respectively (Table 6 ).

The average age of managers of aged care residential services was 50.1 years in 2016. This was older than the average for all industries (44.6 years), and that of the older managers of health services (47.2 years). The average age in 2016 was about one year older than the average in 2006 (49.2 years), and similar to the average increment in all industries during that decade (Table 7).

On average, female managers were slightly younger (49.9 years) than males (50.5 years) in 2016. However, the proportion of males and females varied, with larger proportion of males at older ages, and greater proportion of females in middle age (Fig. 2)

Managers of aged care residential services were older in all categories than the average for all industries and health services in 2006 and 2016. As in other activities, those in the CEO/GM category were older (53.0 years) than other managers in 2016. Contrary to the experience in other activities, managers of ancillary services were older (50.7 years) on average than specialist managers (49.2 years) (Table 8).

\section{FIELD OF STUDY OF MANAGERS}

More than half of managers in aged care residential services in 2016 came from either management and commerce (28.3\%) or health (25.2\%) fields of study in 2016. This was similar to health services but different from the average for all industries in the case of the health field of study (Table 9).

The fields of study of female and male managers of aged care residential services in 2016 followed the general specialisation with a greater proportion of females in the fields of study concerned with health, education, social and related fields, and a larger proportion of males from engineering, architecture, information technology and natural and physical sciences (Table 10). This was also the pattern in 2006. [6]

\section{LEVEL OF EDUCATION OF MANAGERS}

Managers of aged care residential services had a higher level of education at graduate and postgraduate level $(49.0 \%)$ than the average for all industries (39.6\%), but lower than in health services (61.2\%) in 2016. The proportion of those at diploma/certificate level (34.4\%) was about the same as the average for all industries (33.2\%) and greater than the average for health services (24.6\%) (Table 11). The level of education at graduate and postgraduate level in 2016 was somewhat higher than that in 2006 (44.9\%) while the proportion at diploma/certificate level in 2006 (31.9\%) was similar to that in 2016 (Table 11) .[6]

In 2016, the proportion of female managers of aged care residential services at graduate or postgraduate level of education (50.8\%) was higher than that of males $(45.8 \%)$, while males had a larger proportion at diploma/certificate level $(38.5 \%)$ than females (32.1\%) (Table 12).

Again, this was about the same order as that in 2006. [6]

Managers in CEO/GM positions had a higher proportion with graduate and postgraduate degrees (70.1\%) compared with managers in other categories. Specialist managers had the second highest proportion (60.1\%), and service managers had the lowest proportion (15.2\%) at that level. The latter had the highest proportion at diploma/certificate level (53.4\%) (Table 13).

\section{INCOME OF MANAGERS}

Managers of aged care residential services had a slightly higher average weekly income $(\$ 1,903)$ in the week before the 2016 Census than the average for all industries $(\$ 1,894)$. At that rate, it would be the equivalent of an annual 
income of $\$ 99,200$ compared with an average of $\$ 98,800$ for all industries (Table 14).

The average income of managers of aged care residential services rose by $44.6 \%$ in the decade 2006-2016. This increase was larger than that in health services (39.4\%) and the average for all industries (41.2\%) (Table 15).

Managers in the CEO/GM category earned $57.5 \%$ more than the average income of all managers of aged care residential services in 2016. Specialist managers earned $6.5 \%$ more while ancillary service managers $35.7 \%$ less than average in that year. Female managers earned less than males in all categories: $16.6 \%$ less on average (Table 16).

\section{HOURS WORKED BY MANAGERS}

On average, managers of aged care residential services worked 43.6 hours the week before the 2016 census. This was close to the average hours worked one decade earlier in 2006 (43.3 hours). It was 2.4 hours less than the average for all industries (46.0 hours) in 2016 but one hour more than the average for health services (42.6 hours) (Table 17).

CEOS/GMs of aged care residential services worked on average 6.9 hours more than the average of all managers in 2016 . Specialist managers worked about one hour longer and managers of ancillary services 5 hours less than the average. On average, male managers worked (45.0 hours) or about two hours longer per week than females (42.9 hours) (Table 18).

The lower average hours worked by female managers was partly due to the higher proportion of females working parttime (less than 35 hours per week). When the hours worked by full-time managers (working 35 hours or more per week) were assessed, the average difference in hours worked by female and male managers was reduced to 0.4 hours per week (Table 19).

\section{MARITAL STATUS OF MANAGERS}

Most managers of aged care residential services in 2016 were married (64.7\%). This is close to the average in health services and all industries. The proportion of divorced or separated (18.6\%) was higher than that in health services $(13.9 \%)$ and in all industries (11.2\%), while the proportion of never married (14.7\%) was lower than in health services (19.1\%) and in all industries (24.0\%) (Table 20).
However, managers of aged care residential services are much older than the average (Table 7) and marital status is associated with age. Nevertheless, when marital status was standardised for sex and age using all industries as the standard, it showed that the number of actual managers who were divorced or separated was greater than expected given the sex and age distribution, while the number married was close to that expected, and the number of those never married and widowed was less than expected. This was similar to the situation in 2006. [7]

\section{COUNTRY OF BIRTH OF MANAGERS}

The country of birth of managers of aged care residential services in 2016 was similar to the average for all industries. As would be expected, most were born in Australia (68.9\%), about the same proportion as that in all industries (68.7\%). This proportion was a drop from the proportion born in Australia at the time of the 2006 census (73.5\%). Other major changes were the lower proportion of mangers born in European countries outside the United Kingdom and Ireland that fell from $9.4 \%$ in 2006 to $3.6 \%$ in 2016, and the increase in those born elsewhere, mostly in Asia, from $2.6 \%$ in 2006 to $12.6 \%$ in 2016 . The proportion born in the United Kingdom and Ireland remained about the same $110.6 \%$ and $10.5 \%$ in 2006 and 2016) (Table 21).

\section{INDIGENOUS STATUS OF MANAGERS}

The proportion of managers in aged care residential services who declared to have indigenous status was $1.1 \%$ in 2016 . This was higher than the average for all industries $(0.9 \%)$ but lower than the average in health services $(1.7 \%)$ (Table 22). Nevertheless, it was almost double the proportion in 2006 (0.6\%). [7]

\section{TRANSFORMATION REFORM}

Aged care went through substantial changes during the decade 2006-2016 with a greater emphasis on the support of aged people in the community and their own homes. There was also an effort to improve the quality of aged care residential services that was reflected in the larger growth of people employed than the increase in the number of residents of these facilities. 
It resulted in a significant change in the ratio of residents per employee from 1.21 in 2006 to 0.86 in 2016. This was accompanied by the growth in the number of managers at a similar rate as that of employees (average annual rate of increase of $5 \%$ ). Accordingly, the number of managers rose by about $65 \%$ in the ten-year period to reach 10,200 in 2016. This was much greater than the proportional increase in health services and the average for all industries. The ratio of GEO/GM to specialist mangers of $1: 6.1$ and to service managers of 1:2.5 remained about the same during the decade.

Most managers of aged care residential services were female both in 2006 and 2016 (62\% and 64\% respectively). However, the gap between the proportion of female employees and the proportion of managers in aged care residential services continued: $21 \%$ in 2006 and $20 \%$ in 2016. This gap was higher at the CEO/GM/M(nfd) category (34\%) than in the specialist manager category (13\%) and that of service manager (29\%) in 2016.

Managers of aged care residential services in 2016 were considerably older with an average age of 50 years than those in health services (47 years) and the average for all industries (45 years). The increase of about one year in their average age since 2006 was about the same as the rise in the average age of managers in health services and in all industries. CEOS/GMs were three years older than the average of all managers of aged care residential services in 2016. This was similar to health services and in all industries. But it represented a substantial increase during the decade since 2006.

The fields of study of managers of aged care residential services in 2016 were substantially different from that for all industries but close to those of managers in health services, with an emphasis on management and commerce (28\%), health (25\%) and social and related fields (14\%). There was a difference between female and male managers that reflected conventional specialisation of females and males, with female specialising in health and social and related fields of study and males in engineering, architecture and building, and information technology. The level of education of managers of aged care residential services was substantially higher $149 \%$ at graduate and postgraduate level) than the average for all industries (40\%), but lower than that in health services (61\%) in 2016. Female managers had a higher level of education (51\% at graduate and postgraduate level) than males
(46\%) in 2016 with males having a higher proportion at diploma/certificate level (39\%) than females (32\%). Those in the CEO/GM category had a considerable higher proportion at graduate and postgraduate level (70\%) than the average (49\%), and specialist $(60 \%)$ and ancillary service (15\%) managers. The latter had predominately diploma/certificate qualifications (53\%) in 2016.

In association with their lower average level of education than those in health services, aged care residential services earned less $(\$ 1,903)$ per week than those in health services $(\$ 2,089)$, and close to the average for all industries $(\$ 1,894)$ in 2016. During the decade 2006-2016, the increase in their income (45\%) was higher than that of health service managers (39\%) and the average for all industries (41\%). There was gap between the average income of female managers and that of males of $17 \%$ in 2016 . This was most pronounced in the cases of the small group of managers (nfd) (-27\%) and the more numerous specialist managers ($23 \%)$.

Part of this difference was due to the higher proportion of female managers who worked part-time (less that 35 hours per week), as female managers worked on average 43 hours per week and males 45 . The difference between the number of hours worked by female and male managers declined to less than one hour $(-0.4)$ on average when managers working full-time (35 hours or more) were considered. CEOs/GMs worked substantially longer hours (+7 hours per week) than the average for all managers (45 hours per week) in 2016, while ancillary service managers worked less hours than the average (-4 hours per week).

The marital status of aged care residential services was considerably different from that in health services and especially the average for all industries. Some of this difference could be attributed to their average age. However, when the marital status was standardised for sex and age distribution, using all industries as the standard, the actual number of divorced/separated and widowed was much higher than expected and the actual number of never married lower than expected.

There were changes in the country of birth of managers of aged care residential services comparable with those in health services and the average for all industries during the decade 2006-2016. These reflected the increasing proportion of people in Australia born Overseas and change in the origin of migrants. Consequently, the proportion of managers in aged care residential services 
born in Australia declined from 74\% in 2006 to 69\% in 2016. The proportion born in the United Kingdom and Ireland remained about the same (11\%), but that of those born in other European countries fell from $9 \%$ in 2006 to $4 \%$ in 2016 , as migrants from earlier migration from those countries retired. As the origin of migrants from non-European, mostly Asia, increased their proportion of managers rose from $3 \%$ in 2006 to $13 \%$ in 2016.

Another important change was the almost doubling in the proportion of managers with indigenous status from $0.6 \%$ in 2006 to $1.1 \%$ in 2016 .
These findings add to the understanding of the changes that have and are still taking place in aged care residential services, their organisation and who manages them. They also suggest an agenda for research from other sources, regarding the relevance of academic training of managers of aged care residential services, and their continuing education, aimed at improving the competence of these managers in enhancing the quality and effectiveness of these services for the fast growing population of aged people in Australia.

FIGURE 1: SPECIALIST AND SERVICE MANAGERS PER GENERAL MANAGER, AGED CARE RESIDENTIAL SERVICES, AUSTRALIA, 2006 AND 2016

CEO/GM/M(nfd) (1)

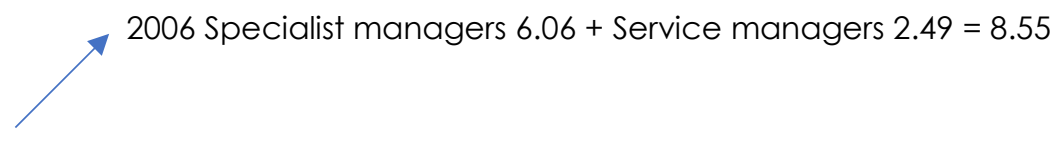

2016 Specialist managers $5.97+$ Service managers $2.53=8.50$

Source: Table 4. Source: ABS (2017).

Fig.2 Age distribution of managers, aged care reidential services by sex, Australia, 2016

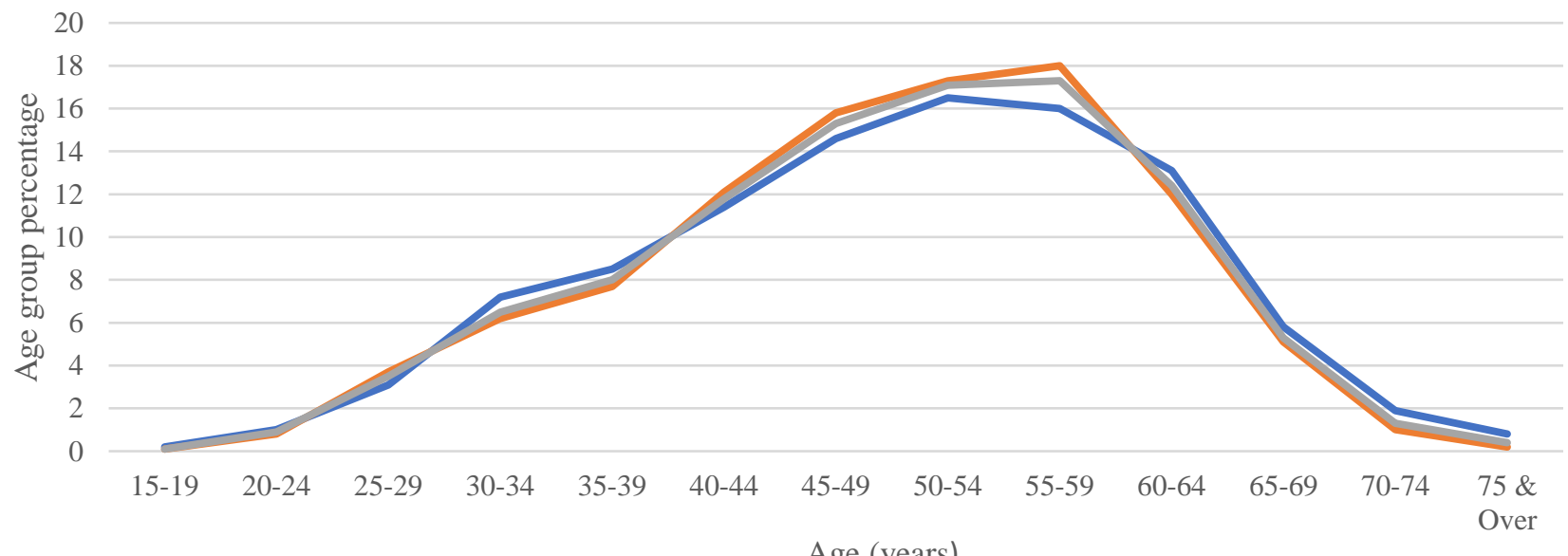

Age (years)

$\longrightarrow$ Males $\longrightarrow$ Feamles $\longrightarrow$ Persons 
tABLE 1: AGED CARE ReSidential SERVICES tARGet POPULATION, RESIDENTS, PEOPLE EMPLOYED AND MANAGERS, AUSTRALIA, 2006 AND 2016

\begin{tabular}{|c|c|c|c|}
\hline \multirow{2}{*}{$\begin{array}{l}\text { TARGET POPULATION, RESIDENTS, } \\
\text { EMPLOYEES \& MANAGERS }\end{array}$} & \multicolumn{2}{|l|}{ NUMBER } & \multirow{2}{*}{$\begin{array}{l}\text { AVERAGE } \\
\text { ANNUAL } \\
\text { GROWTH \% }\end{array}$} \\
\hline & 2006 & 2016 & \\
\hline Population 70 years of age and over & $1,887,000$ & $2,487,800$ & 2.76 \\
\hline Residents of aged care residential facilities & 154,900 & 181,000 & 1.56 \\
\hline People employed by aged care residential services & 128,300 & 211,600 & 5.00 \\
\hline Managers of aged care residential services & 6,200 & 10,200 & 5.01 \\
\hline
\end{tabular}

tABle 1: AGED CARE RESIDENTIAL SERVICES tARGET POPULATION, RESIDENTS, PEOPLE EMPLOYED AND MANAGERS, AUSTRALIA, 2006 AND 2016

\begin{tabular}{|c|c|c|c|}
\hline \multirow{2}{*}{$\begin{array}{l}\text { TARGET POPULATION, RESIDENTS, } \\
\text { EMPLOYEES \& MANAGERS }\end{array}$} & \multicolumn{2}{|l|}{ NUMBER } & \multirow{2}{*}{$\begin{array}{l}\text { AVERAGE } \\
\text { ANNUAL } \\
\text { GROWTH \% }\end{array}$} \\
\hline & 2006 & 2016 & \\
\hline Population 70 years of age and over & $1,887,000$ & $2,487,800$ & 2.76 \\
\hline Residents of aged care residential facilities & 154,900 & 181,000 & 1.56 \\
\hline People employed by aged care residential services & 128,300 & 211,600 & 5.00 \\
\hline Managers of aged care residential services & 6,200 & 10,200 & 5.01 \\
\hline
\end{tabular}

Sources: Martins \& Isouard (2014); ABS (2017). 
TABLE 2: AGED CARE RESIDENTIAL SERVICES RESIDENTS PER TARGET POPULATION, RESIDENTS, EMPLOYEE AND MANAGERS, AND EMPLOYEES PER MANAGERS, AUSTRALIA, 2006 AND 2016

\begin{tabular}{|l|l|l|l|}
\hline RATIOS & 2006 & 2016 & $\begin{array}{l}\text { INCREASE } \\
2006-2016 \\
\%\end{array}$ \\
\hline Number of residents per 1,000 people $>69$ years of age & 82.1 & 72.8 & -11.4 \\
Number of residents per employee & 1.207 & 0.856 & -29.1 \\
\hline Number of residents per manager & 25.0 & 17.0 & -29.2 \\
\hline
\end{tabular}

Sources: Martins \& Isovard (2014); ABS (2017).

TABLE 3: MANAGERS IN AGED CARE RESIDENTIAL SERVICES, HEALTH SERVICES AND ALL INDUSTRIES, AUSTRALIA, 2006 AND 2016

\begin{tabular}{|c|c|c|c|}
\hline \multirow[b]{2}{*}{ MANAGER PLACE OF EMPLOYMENT } & \multicolumn{2}{|c|}{ NO. OF MANAGERS (000S) } & \multirow{2}{*}{$\begin{array}{l}\text { INCREASE } \\
2006-2016 \\
\%\end{array}$} \\
\hline & 2006 & 2016 & \\
\hline Aged care residential services & 6.2 & 10.2 & 65.0 \\
\hline Health services & 19.4 & 29.4 & 51.5 \\
\hline All industries & $1,025.4$ & $1,248.6$ & 21.8 \\
\hline
\end{tabular}

Sources: Martins \& Isovard (2014); ABS (2017). 
TABLE 4: MANAGERS IN AGED CARE RESIDENTIAL SERVICES PER CATEGORY, AUSTRALIA, 2006 AND 2016

\begin{tabular}{|l|l|l|l|}
\hline \multirow{2}{*}{ MANAGER CATEGORY } & \multicolumn{2}{l|}{ NO. OF MANAGERS } & \multicolumn{2}{l|}{ INCREASE } \\
\cline { 2 - 4 } & 2006 & $2006-2016$ \\
\hline CEO/GM & & & $\%$ \\
Managers (nfd) & 123 & 972 & 84.8 \\
\hline Sub-total & 649 & 106 & -13.8 \\
\hline Specialist managers & 3,932 & 1,078 & 66.1 \\
\hline Service managers & 1,619 & 6,432 & 63.6 \\
\hline All & 6,200 & 2,723 & 68.2 \\
\hline
\end{tabular}

Note: (CEO/GM) chief executive officers and general managers; (Managers nfd) managers not further defined; (Specialist managers) managers who perform specialist functions such as finance, human resources, information technology, medical and other clinical services, nursing and allied services; (Service managers) managers concerned with catering, cleaning, maintenance and other ancillary services.

Sources: Martins \& Isouard (2014); ABS (2017).

TABLE 5: AGED CARE RESIDENTIAL SERVICES PROPORTION OF FEMALE EMPLOYEES AND MANAGERS, AUSTRALIA, 2006 AND 2016

\begin{tabular}{|l|l|l|l|}
\hline \multirow{2}{*}{ YEAR } & \multicolumn{2}{|c|}{ FEMALE \% } & \multirow{2}{*}{$\%$ GAP } \\
\cline { 2 - 4 } & EMPLOYEES & MANAGERS & \multirow{2}{*}{ MANAGERS-EMPLOYEES } \\
\hline 2006 & 87.4 & 66.2 & -21.2 \\
\hline 2016 & 83.7 & 64.2 & -19.5 \\
\hline
\end{tabular}

Sources: Martins \& Isouard (2014); ABS (2017). 
TABLE 6: AGED CARE RESIDENTIAL SERVICES PROPORTION OF FEMALE MANAGERS BY CATEGORY, AUSTRALIA, 2006 AND 2016

\begin{tabular}{|l|l|l|l|}
\hline \multirow{2}{*}{ MANAGER CATEGORY } & \multicolumn{2}{|l|}{ FEMALE \% } & \multirow{2}{*}{$2016 \%$ GAP } \\
\cline { 2 - 4 } & 2006 & 2016 & $\begin{array}{l}\text { MANAGERS- } \\
\text { EMPLOYEES }\end{array}$ \\
\hline \multirow{2}{*}{ CEO/GM } & & & -35.4 \\
Managers (nfd) & 42.6 & 48.3 & -22.4 \\
\hline & 56.1 & 61.3 & -34.2 \\
Specialist managers & 45.1 & 49.5 & -12.8 \\
Service managers & 55.7 & 70.9 & -29.3 \\
\hline & & 54.4 & -19.5 \\
\hline All & 66.2 & & \\
\hline
\end{tabular}

Note: (CEO/GM) chief executive officers and general managers; (Managers nfd) managers not further defined.

Sources: Martins \& Isouard (2014); ABS (2017).

TABLE 7: AVERAGE AGE OF AGED CARE RESIDENTIAL SERVICES, HEALTH SERVICES AND ALL INDUSTRIES, AUSTRALIA, 2006 AND 2016

\begin{tabular}{|l|l|l|l|}
\hline MEASURES OF CENTRAL TENDENCY & $\begin{array}{l}\text { AGED CARE } \\
\text { RESIDENTIAL SERVICES }\end{array}$ & HEALTH SERVICES & ALL INDUSTRIES \\
\hline 2016 & & & \\
Average age (years) & 50.1 & 47.2 & 44.6 \\
Median age (years) & 51.1 & 47.6 & 44.5 \\
Standard deviation (years) & 11.1 & 10.9 & 12.0 \\
Coefficient of variation & 0.22 & 0.23 & 0.27 \\
\hline & & & \\
2006 & 49.2 & 46.0 & 43.5 \\
Average age (years) & 50.1 & 46.6 & 11.6 \\
Median age (years) & 10.0 & 10.0 & 0.27 \\
Standard deviation (years) & 0.20 & 0.22 & \\
Coefficient of variation & & & \\
\hline
\end{tabular}

Sources: Martins \& Isouard (2012b); ABS (2017). 
TABLE 8: AVERAGE AGE OF AGED CARE RESIDENTIAL SERVICES, HEALTH SERVICES AND ALL INDUSTRIES BY CATEGORY, AUSTRALIA, 2006 AND 2016

\begin{tabular}{|c|c|c|c|}
\hline \multirow[b]{2}{*}{ MANAGER CATEGORY } & \multicolumn{3}{|l|}{ AGE (YEARS) } \\
\hline & $\begin{array}{l}\text { AGED CARE } \\
\text { RESIDENTIAL SERVICES }\end{array}$ & HEALTH SERVICES & ALL INDUSTRIES \\
\hline \multicolumn{4}{|l|}{2016} \\
\hline CEO/GM & 53.0 & 49.8 & 49.1 \\
\hline Manager (nfd) & 49.3 & 48.0 & 47.3 \\
\hline Specialist & 49.2 & 47.0 & 44.8 \\
\hline Service & 50.7 & 45.7 & 42.9 \\
\hline All & 50.1 & 47.2 & 44.6 \\
\hline \multicolumn{4}{|l|}{2006} \\
\hline CEO/GM & 50.6 & 47.8 & 47.4 \\
\hline Manager (nfd) & 53.1 & 47.4 & 47.2 \\
\hline Specialist & 49.5 & 45.7 & 43.5 \\
\hline Service & 48.8 & 45.4 & 41.9 \\
\hline All & 49.2 & 46.0 & 43.5 \\
\hline
\end{tabular}

Note: (CEO/GM) chief executive officers and general managers; (Managers nfd) managers not further defined:

Sources: Martins \& Isovard (2012b); ABS (2017).

TABLE 10: FIELD OF STUDY OF MANAGERS IN AGED CARE RESIDENTIAL SERVICES BY SEX, AUSTRALIA, 2016

\begin{tabular}{|l|l|l|l|}
\hline \multirow{2}{*}{ FIELD OF STUDY } & \multicolumn{2}{l|}{$\%$} & \multicolumn{2}{l|}{} \\
\cline { 2 - 4 } & FEMALE & MALE & PERSONS \\
\hline Management \& commerce & 25.6 & 33.2 & 28.3 \\
Health & 34.5 & 8.5 & 25.2 \\
Social \& related fields & 15.7 & 9.6 & 13.5 \\
Food \& hospitality & 3.5 & 5.5 & 4.2 \\
Engineering & 0.4 & 11.0 & 4.2 \\
Architecture \& building & 0.3 & 8.3 & 3.1 \\
Education & 2.7 & 1.7 & 2.4 \\
Information technology & 0.3 & 3.6 & 1.5 \\
Natural \& physical sciences & 0.5 & 1.2 & 0.8 \\
Other* & 16.3 & 17.5 & 16.7 \\
\hline All & 100.0 & 100.0 & 100.0 \\
\hline
\end{tabular}

Note: $(*)$ Other includes managers whose field of study was inadequately described, not stated or without a field of study (in relation to post-school qualifications). Figures may not add up due to rounding.

Source: ABS (2017). 
TABLE 9: FIELD OF STUDY OF MANAGERS IN AGED CARE RESIDENTIAL SERVICES, HEALTH SERVICES AND ALL INDUSTRIES, AUSTRALIA, 2016

\begin{tabular}{|c|c|c|c|}
\hline \multirow[b]{2}{*}{ FIELD OF STUDY } & \multicolumn{3}{|l|}{$\%$} \\
\hline & $\begin{array}{l}\text { AGED CARE } \\
\text { RESIDENTIAL } \\
\text { SERVICES }\end{array}$ & $\begin{array}{l}\text { HEALTH } \\
\text { SERVICES }\end{array}$ & ALL INDUSTRIES \\
\hline Management \& commerce & 28.3 & 29.3 & 26.8 \\
\hline Health & 25.2 & 28.4 & 3.2 \\
\hline Social \& related fields & 13.5 & 10.7 & 10.5 \\
\hline Food \& hospitality & 4.2 & 1.7 & 3.3 \\
\hline Engineering & 4.2 & 3.7 & 11.5 \\
\hline Architecture \& building & 3.1 & 0.9 & 5.7 \\
\hline Education & 2.4 & 2.4 & 4.1 \\
\hline Information technology & 1.5 & 2.7 & 3.5 \\
\hline Natural \& physical sciences & 0.8 & 5.2 & 2.7 \\
\hline Other* & 16.7 & 15.1 & 28.7 \\
\hline All & 100.0 & 100.0 & 100.0 \\
\hline Relative difference index & 53.4 & 50.9 & Standard \\
\hline
\end{tabular}

Note: The relative difference index $=\left[\sum\left|\left\{\left(a_{i} / b_{i}\right)^{*} 100\right\}-100\right|\right] /\left(2^{*} n\right) ;\left(a_{i}\right)$ is the proportion of managers with field of study $(i)$ in given service; $\left(b_{i}\right)$ is the proportion of managers with field of study (i) in all industries; ( $n$ ) is the number of fields of study. (*) Other includes managers whose field of study was inadequately described, not stated or without a field of study (in relation to post-school qualifications). Figures may not add up due to rounding.

Source: ABS (2017).

TABLE 11: LEVEL OF EDUCATION OF MANAGERS IN AGED CARE RESIDENTIAL SERVICES, HEALTH SERVICES AND ALL INDUSTRIES, AUSTRALIA, 2016

\begin{tabular}{|c|c|c|c|}
\hline \multirow[b]{2}{*}{ LEVEL OF EDUCATION } & \multicolumn{3}{|l|}{$\%$} \\
\hline & $\begin{array}{l}\text { AGED } \\
\text { RESIDENTIAL } \\
\text { SERVICES }\end{array}$ & HEALTH SERVICES & ALL INDUSTRIES \\
\hline Postgraduate & 18.4 & 29.4 & 14.2 \\
\hline Bachelor degree & 30.6 & 31.8 & 25.4 \\
\hline Graduate subtotal & 49.0 & 61.2 & 39.6 \\
\hline Diploma/certificate & 34.4 & 24.6 & 33.2 \\
\hline Other* & 16.6 & 14.2 & 27.1 \\
\hline All & 100.0 & 100.0 & 100.0 \\
\hline Relative difference index & 11.6 & 36.5 & Standard \\
\hline
\end{tabular}

Note: $\left(^{*}\right)$ Other includes managers whose field of study was inadequately described, not stated or without a post-school qualifications. Figures may not add up due to rounding. The relative difference index $=\left[\Sigma\left|\left\{\left(a_{i} / b_{i}\right)^{*} 100\right\}-100\right|\right] /(2 * n) ;\left(a_{i}\right)$ is the proportion of managers with level of education (i) in given service; $\left(b_{i}\right)$ is the proportion of managers with level of education (i) in all industries; $(n)$ is the number of levels of study.

Source: ABS (2017). 
TABLE 12: LEVEL OF EDUCATION OF MANAGERS IN AGED CARE RESIDENTIAL SERVICES BY SEX, AUSTRALIA, 2016

\begin{tabular}{|l|l|l|l|}
\hline \multirow{2}{*}{ LEVEL OF EDUCATION } & \multicolumn{2}{l}{ \% } & \multicolumn{2}{l|}{} & \multicolumn{2}{l|}{ PERSONS } \\
\cline { 2 - 4 } & FEMALES & MALES & 18.4 \\
\hline Postgraduate & 18.2 & 18.7 & 30.6 \\
Bachelor degree & 32.6 & 27.0 & 49.0 \\
\cline { 2 - 4 } Graduate subtotal & 50.8 & 45.8 & 34.4 \\
Diploma/certificate & 32.1 & 38.5 & 16.6 \\
\hline Other* & 17.1 & 15.7 & 100.0 \\
\hline All & 100.0 & 100.0 & \\
\hline
\end{tabular}

Note: $(*)$ Other includes managers whose field of study was inadequately described, not stated or without a post-school qualifications. Figures may not add up due to rounding.

Source: ABS (2017).

TABLE 13: LEVEL OF EDUCATION OF MANAGERS IN AGED CARE RESIDENTIAL SERVICES BY CATEGORY, AUSTRALIA, 2016

\begin{tabular}{|c|c|c|c|c|c|}
\hline \multirow[b]{2}{*}{ LEVEL OF EDUCATION } & \multicolumn{5}{|l|}{$\%$} \\
\hline & CEO/GM & $M(N F D)$ & SPECIALIST & SERVICE & ALL \\
\hline Postgraduate & 33.4 & 20.8 & 21.9 & 4.6 & 18.4 \\
\hline Bachelor degree & 36.6 & 30.2 & 38.2 & 10.6 & 30.6 \\
\hline Graduate subtotal & 70.1 & 50.9 & 60.1 & 15.2 & 49.0 \\
\hline Diploma/certificate & 17.6 & 27.4 & 29.0 & 53.4 & 34.4 \\
\hline Other* & 12.3 & 21.7 & 10.9 & 31.4 & 16.6 \\
\hline All & 100.0 & 100.0 & 100.0 & 100.0 & 100.0 \\
\hline
\end{tabular}

Note: (*) Other includes managers whose field of study was inadequately described, not stated or without a post-school qualifications. (CEO/GM) are chief executive officers and general managers; (Mnfd) are managers not further defined. Figures may not add up due to rounding.

Source: ABS (2017)

TABLE 14: AVERAGE WEEKLY INCOME OF MANAGERS IN AGED CARE RESIDENTIAL SERVICES, HEALTH SERVICES AND ALL INDUSTRIES, AUSTRALIA, 2016

\begin{tabular}{|l|l|l|l|}
\hline MEASURES OF CENTRAL TENDENCY & $\begin{array}{l}\text { AGED CARE } \\
\text { RESIDENTIAL SERVICES }\end{array}$ & HEALTH SERVICES & ALL INDUSTRIES \\
\hline Average weekly income (\$) & 1,903 & 2,089 & 1,894 \\
Median weekly income (\$) & 1,676 & 1,077 & 1,589 \\
Standard deviation (\$) & 1,046 & 0.52 & 0.63 \\
Coefficient of variation & 0.55 & 1,185 \\
\hline
\end{tabular}

Note: The average weekly income refers gross weekly income the week before the census. The figures exclude managers who did not state their weekly income (1.1\%).

Source: ABS (2017). 
TABLE 15: AVERAGE WEEKLY INCOME OF MANAGERS IN AGED CARE RESIDENTIAL SERVICES, HEALTH SERVICES AND ALL INDUSTRIES, AUSTRALIA, 2006 AND 2016

\begin{tabular}{|l|l|l|l|}
\hline YEAR & $\begin{array}{l}\text { AGED CARE } \\
\text { RESIDENTIAL SERVICES }\end{array}$ & HEALTH SERVICES & ALL INDUSTRIES \\
\hline $\begin{array}{l}\text { 2016 Average weekly income (\$) } \\
2006 \text { Average weekly income (\$) }\end{array}$ & 1,903 & 2,089 \\
1,316 & 399 & 1,894 \\
\hline increase 2006-2016 & 44.6 & 41.2 \\
\hline
\end{tabular}

Note: The average weekly income refers gross weekly income the week before the census. The figures exclude managers who did not state their weekly income in 2016 and 2006 about $1 \%$ in the case of aged care residential services and health services and $1.5 \%$ in all industries.

Sources: Martins \& Isouard (2012c); ABS (2017).

TABLE 16: AVERAGE WEEKLY INCOME AGED CARE RESIDENTIAL MANAGERS BY SEX AND CATEGORY, AUSTRALIA, 2016

\begin{tabular}{|l|l|l|l|l|}
\hline \multirow{2}{*}{ MANAGER CATEGORY } & \multicolumn{2}{l|}{ AVERAGE WEEKLY INCOME (\$) } & \multicolumn{2}{l|}{$\begin{array}{l}\text { FEMALE } \\
\text { BELOW MALE }\end{array}$} \\
\cline { 2 - 5 } & FEMALE & MALE & PERSONS & \\
\hline CEO/GM & 2,747 & 3,212 & 2,997 & -16.9 \\
Managers (nfd) & 1,949 & 2,472 & 2,056 & -26.8 \\
Specialist managers & 1,907 & 2,349 & 2,027 & -23.2 \\
Service managers & 1,154 & 1,287 & 1,223 & -11.5 \\
\hline All & 1,799 & 2,098 & 1,903 & -16.6 \\
\hline CEO/GM \% above average & +52.7 & +53.1 & +57.5 & \\
\hline
\end{tabular}

Note: The average weekly income refers gross weekly income the week before the census. The figures exclude managers who did not state their weekly income (1.1\%). (CEO/GM) are chief executive officers and general managers; (Managers nfd) are managers not further defined.

Source: $A B S$ (2017).

TABLE 17: AVERAGE WEEKLY HOURS WORKED BY MANAGERS IN AGED CARE RESIDENTIAL SERVICES, HEALTH SERVICES AND ALL INDUSTRIES, AUSTRALIA, 2016 AND 2006

\begin{tabular}{|l|l|l|l|}
\hline MEASURES OF CENTRAL TENDENCY & $\begin{array}{l}\text { AGED CARE } \\
\text { RESIDENTIAL SERVICES }\end{array}$ & HEALTH SERVICES & ALL INDUSTRIES \\
\hline 2016 & 43.6 & 42.6 & 46.0 \\
Average weekly hours worked & 40.2 & 40.4 & 40.8 \\
Median weekly hours worked & 16.6 & 17.1 & 17.8 \\
Standard deviation (hours) & 0.38 & 0.40 & 0.41 \\
\hline 2006 & 43.3 & 41.9 & 46.9 \\
Average weekly hours worked & 39.8 & 39.7 & 43.6 \\
Median weekly hours worked & 16.1 & 17.8 & 19.6 \\
Standard deviation (hours) & 0.42 & 0.42 & 0.42 \\
\hline Coefficient of variation & +0.7 & +0.7 & -0.9 \\
\hline 2016-2006 & & & \\
\hline
\end{tabular}


Note: The average weekly hours worked refers to the hours worked the week before the census. The figures exclude managers who did not state the number of hours worked: aged care residential services $0.4 \%, 0.5 \%$ in health services and $0.9 \%$ in all industries in 2016 ; $1.2 \%$ in aged care residential services,

$1.1 \%$ in health services, $1.7 \%$ in all industries in 2006

Source: Martins \& Isouard (2012d); ABS (2017).

TABLE 18: AVERAGE WEEKLY HOURS WORKED BY AGED CARE RESIDENTIAL MANAGERS BY SEX AND CATEGORY, AUSTRALIA, 2016

\begin{tabular}{|c|c|c|c|c|}
\hline \multirow[b]{2}{*}{ MANAGER CATEGORY } & \multicolumn{3}{|c|}{ AVERAGE WEEKLY HOURS WORKED } & \multirow{2}{*}{$\begin{array}{l}\text { FEMALE } \\
\text { BELOW/ABOVE } \\
\text { MALE HOURS }\end{array}$} \\
\hline & FEMALE & MALE & PERSONS & \\
\hline CEO/GM & 49.1 & 51.7 & 50.5 & -2.6 \\
\hline Managers (nfd) & 48.4 & 39.7 & 44.8 & +8.7 \\
\hline Specialist managers & 43.8 & 46.8 & 44.7 & -3.0 \\
\hline Service managers & 37.8 & 39.7 & 38.7 & -1.9 \\
\hline All & 42.9 & 45.0 & 43.6 & -2.1 \\
\hline
\end{tabular}

Note: The average weekly hours worked refers to the hours worked the week before the census. The figures exclude managers who did not state the number of hours worked (0.4\%). (CEO/GM) are chief executive officers and general managers; (Managers nfd) are managers not further defined. Source: Martins \& Isouard (2012d); ABS (2017).

TABLE 19: AVERAGE WEEKLY HOURS WORKED BY FULL-TIME MANAGERS OF AGED CARE RESIDENTIAL BY SEX AND CATEGORY, AUSTRALIA, 2016

\begin{tabular}{|c|c|c|c|c|}
\hline \multirow[b]{2}{*}{ MANAGER CATEGORY } & \multicolumn{3}{|c|}{ AVERAGE WEEKLY HOURS WORKED } & \multirow{2}{*}{$\begin{array}{l}\text { FEMALE } \\
\text { BELOW/ABOVE } \\
\text { MALE HOURS }\end{array}$} \\
\hline & FEMALE & MALE & PERSONS & \\
\hline CEO/GM & 53.9 & 55.8 & 54.9 & -1.9 \\
\hline Managers (nfd) & 48.4 & 45.4 & 47.3 & +3.0 \\
\hline Specialist managers & 48.2 & 49.4 & 48.6 & -1.2 \\
\hline Service managers & 45.4 & 43.8 & 44.6 & +1.6 \\
\hline All & 48.1 & 48.5 & 48.2 & -0.4 \\
\hline
\end{tabular}

Note: Full-time managers are those who worked 35 hours or more the week before the census. The figures exclude managers who did not state the number of hours worked (0.4\%). (CEO/GM) are chief executive officers and general managers; (Managers nfd) are managers not further defined. Source: Martins \& Isouard (2012d); ABS (2017). 
TABLE 20: MARITAL STATUS OF MANAGERS IN AGED CARE RESIDENTIAL SERVICES, HEALTH SERVICES AND ALL INDUSTRIES, AUSTRALIA, 2016

\begin{tabular}{|c|c|c|c|}
\hline \multirow[b]{2}{*}{ MARITAL STATUS } & \multicolumn{3}{|l|}{$\%$} \\
\hline & $\begin{array}{l}\text { AGED CARE } \\
\text { RESIDENTIAL SERVICES }\end{array}$ & HEALTH SERVICES & ALL INDUSTRIES \\
\hline Never married & 14.7 & 19.1 & 24.0 \\
\hline Married & 64.7 & 65.9 & 63.9 \\
\hline Divorced/separated & 18.6 & 13.9 & 11.2 \\
\hline Widowed & 2.0 & 1.1 & 0.9 \\
\hline All & 100.0 & 100.0 & 100.0 \\
\hline
\end{tabular}

Source: ABS (2017).

TABLE 21: COUNTRY OF BIRTH OF MANAGERS IN AGED CARE RESIDENTIAL SERVICES, HEALTH SERVICES AND ALL INDUSTRIES, AUSTRALIA, 2006 AND 2016

\begin{tabular}{|c|c|c|c|}
\hline \multirow[b]{2}{*}{ COUNTRY OF BIRTH } & \multicolumn{3}{|l|}{$\%$} \\
\hline & $\begin{array}{l}\text { AGED CARE } \\
\text { RESIDENTIAL SERVICES }\end{array}$ & HEALTH SERVICES & ALL INDUSTRIES \\
\hline \multicolumn{4}{|l|}{2016} \\
\hline Australia & 68.9 & 69.7 & 68.7 \\
\hline New Zealand and Oceania & 4.4 & 3.7 & 3.8 \\
\hline United Kingdom \& Ireland & 10.5 & 9.7 & 7.7 \\
\hline Other Europe & 3.6 & 2.9 & 3.8 \\
\hline Other & 12.6 & 14.0 & 16.0 \\
\hline 2016 All & 100.0 & 100.0 & 100.0 \\
\hline \multicolumn{4}{|l|}{2006} \\
\hline Australia & 73.5 & 74.3 & 73.2 \\
\hline New Zealand and Oceania & 3.9 & 3.0 & 3.5 \\
\hline United Kingdom \& Ireland & 10.6 & 10.7 & 8.4 \\
\hline Other Europe & 9.4 & 8.4 & 10.9 \\
\hline Other & 2.6 & 3.6 & 4.1 \\
\hline 2006 All & 100.0 & 100.0 & 100.0 \\
\hline
\end{tabular}

Source: Martins \& Isouard (2012d); ABS (2017). 
TABLE 22: INDIGENOUS STATUS OF MANAGERS IN AGED CARE RESIDENTIAL SERVICES, HEALTH SERVICES AND ALL INDUSTRIES, AUSTRALIA, 2016

\begin{tabular}{|l|l|l|l|}
\hline \multirow{2}{*}{ INDIGENOUS STATUS } & \multicolumn{2}{|l|}{$\%$} & \multicolumn{1}{|l|}{ CARE } \\
\cline { 2 - 4 } & $\begin{array}{l}\text { AGED } \\
\text { RESIDENTIAL SERVICES }\end{array}$ & HEALTH SERVICES & ALL INDUSTRIES \\
\hline \multirow{2}{*}{ Indigenous } & 1.1 & 1.7 & 0.9 \\
\hline Non-indigenous & 98.9 & 98.3 & 99.1 \\
\hline All & 100.0 & 100.0 & 100.0 \\
\hline
\end{tabular}

Note: The proportion of people who did not state their indigenous status was $0.4 \%$ in all activities.

Source: ABS (2017).

\section{References}

1. Australian Bureau of Statistics (ABS). 2016 Census of Population and Housing. Customised Data Report. (Tabulations prepared in accordance with specifications made by the authors). Canberra: ABS 2017.

2. Australian Institute of Health and Welfare (AlHW). Residential aged care in Australia 2005-06. Canberra: AlHW 2007.

3. Department of Health. 2015-16 Report on the operation of the Aged Care Act 1997. CanberraDOH 2016.

4. Martins, J. M. \& G. Isouard. Health service managers in Australia. Part 1: service, geographical and category distribution. Asia Pacific Journal of Health Management, 2012a; 7 (2): 16-28.

5. Martins, J. M. \& G. Isouard. Health service managers in Australia. Part 2: age and sex characteristics. Asia Pacific Journal of Health Management, 2012b;7 (2): 29-42.

6. Martins, J. M. \& G. Isouard. Health service managers in Australia. Part 3: field of study, level of education and income. Asia Pacific Journal of Health Management, 2012c; 7 (2): 43-58.
7. Martins, J. M. \& G. Isouard. Health service managers in Australia. Part 4: hours of work, marital status, country of birth and Indigenous status. Asia Pacific Journal of Health Management, 2012d; 7 (2): 59-70.

8. Martins, J. M. \& G. Isouard. Managers of aged care residential services. Asia Pacific Journal of Health Management, 2014; 9 (2): 21-34 